\title{
The Effect of Concanavalin A on the Replication of Rotavirus (SA-11) in Cell Culture
}

\author{
Beatriz S. Hasenack ${ }^{1}$; Maria Valéria J. Botelho ${ }^{1}$; Flávio Lauretti ${ }^{1}$; Fernando L. de Melo ${ }^{1}$; \\ Janaina M. Orlandi ${ }^{1}$; Rosa Elisa C. Linhares ${ }^{1}$; Marli Ueda ${ }^{2}$ and Carlos M. Nozawa ${ }^{1 *}$ \\ ${ }^{1}$ Departamento de Microbiologia; CCB; Universidade Estadual de Londrina;. Caixa Postal 6001; CEP 86051-970; \\ Londrina - Pr, Brasil. ${ }^{2}$ Seção de Microscopia Eletrônica; Instituto Adolfo Lutz; Av. Dr. Arnaldo, 355; CEP 01246- \\ 902; São Paulo - SP, Brasil
}

\begin{abstract}
Rotavirus $(R V)$ strain SA-11 was studied with respect to its infectivity in MA-104 cell cultures and the effect of concanavalin A (ConA). Receptors for ConA at the surface of MA-104 cell were determined by fluorescence assay and specifically inhibited by D-mannose. The kinetics of virus growth was carried out by plaque assay. Electron microscopy and polyacrylamide gel electrophoresis were used for monitoring the experiments. It was concluded that $R V$ replication was not affected consistently by ConA, however it interfered with the development of cytopathic effect (CPE) without altering virus yields.
\end{abstract}

Key words: Rotavirus, Concanavalin A, Cell culture

\section{INTRODUCTION}

Rotaviruses (RV) are agents of acute diarrhea in mammals and birds (Kapikian \& Chanock, 1996; Burke \& Desselberger, 1996). Virion genome is formed by eleven segments of double-stranded RNA involved by a concentric triple-layered protein shell (Kapikian \& Chanock, 1996). The outer layer is constituted by VP4 and VP7 proteins being the former associated to hemagglutinin activity (some strains of RV), attachment and virulence (Bridger et al., 1998; Kirkwood et al., 1998). The latter, a glycoprotein, seems to be involved in cell penetration either by promoting the stability of VP4 or enhancing its activity (Prasad \& Estes, 1997). VP4 is synthesized in free ribosomes while VP7 in ribosomes associated to the endoplasmic reticulum where it is glycosylated. The number of sites and locations of VP7 glycosylation depend upon the strain of RV albeit the glycans are all of high-mannose type (Both et al,1994; Reading et al., 1998). The interaction of RV-cell receptors has been studied for the identification of molecules involved and to better understanding of cell binding and penetration processes (Méndez et al., 1996; Ludert et al., 1996; Rolsma et al, 1998). The identification of viral and cell receptors can be done by several methods (Haywood, 1994), and among them, lectins are used for monitoring early stages for virus-cell interaction due to their specificity to sugar residues (Murray, 1994). Concanavalin A (ConA), a lectin from jack bean, binds specifically to mannosyl and glycosyl

\footnotetext{
* Author for correspondence
} 
residues. This lectin has been extensively used for the study of virus attachment to host cells and characterization of glycoproteins involved, mainly concerned to the enveloped viruses (Calafat \& Hageman, 1972; Okada \& Kim, 1972; Miki, 1980; Conti \& Tsiang, 1985; Grail \& Norval, 1986; Kopecky et al., 1991; Okamoto et al, 1997). Svensson (1984) demonstrated that RV express mannosyl residues in VP7. Therefore, we attempted to establish a model for enhancing or inhibiting RV (SA-11) infection in cell culture by Con A. The study was motivated due to the unavailability of datum on this respect; the presence of mannosyl residues on the virus surface protein (VP7); and the possibility of an alternative mechanism of virus binding to the host cell.

\section{MATERIALS AND METHODS}

Cell and virus: MA-104 cell cultures (fetal monkey kidney) were cultivated in Dulbecco's Modified Eagle Medium (DMEM) supplemented with $100 \mathrm{UI} / \mathrm{ml}$ penicillin, $100 \mu \mathrm{g} / \mathrm{ml}$ streptomycin, $2.5 \mu \mathrm{g} / \mathrm{ml}$ fungizon and $10 \%$ fetal bovine serum (FBS), and in $5 \% \mathrm{CO}_{2}$ ambient when required. Simian rotavirus (SA-11) was always pretreated with $30 \mu \mathrm{g} / \mathrm{ml}$ of crystalline trypsin at $37^{\circ} \mathrm{C}$ for 30 min prior to inoculation. MA-104 cell cultures used for rotavirus growth showing $60 \%$ of cytopathic effect (CPE) were submitted to three cycles of freezing/thawing, centrifuged at 2,000xg for $10 \mathrm{~min}$ and maintained at $-20^{\circ} \mathrm{C}$. This virus suspension was used throughout at a multiplicity of infection of approximately 1.

Concanavalin A (ConA): ConA type IV (Sigma, USA) from Canavalia ensiformis was prepared as a stock solution at $100 \mu \mathrm{g} / \mathrm{ml}$ in phosphate-buffered

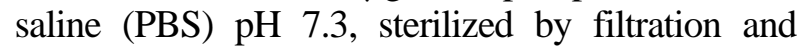
maintained at $-20^{\circ} \mathrm{C}$.

Plaque assay titration: Four hundred microliters of the inoculum diluted to the tenth were seeded in a 24-well tissue culture plate with MA-104 cell culture at $70 \%$ confluence. After the attachment, the inoculum excess was removed, cell monolayers washed with PBS and overlaid with melted $0.5 \%$ nutrient agarose containing antibiotics, $10 \mu \mathrm{g} / \mathrm{ml}$ of crystalline trypsin and $100 \mu \mathrm{g} / \mathrm{ml}$ of DEAE-dextran. Agarose nutrient overlay was allowed to solidification, and plates were incubated upside down at $37^{\circ} \mathrm{C}$ in $5 \% \mathrm{CO}_{2}$ ambient for 5 days. Monolayers were fixed with $10 \%$ buffered-formaldehyde for $24 \mathrm{~h}$ at room temperature $\left( \pm 25^{\circ} \mathrm{C}\right)$ and overlay melted in microwave (75 sec at medium power level). Plaques counting were performed after monolayers staining with $0.5 \%$ crystal violet (Fig.1).

Fluorescence assay: Cell monolayers grown in coverslips were washed twice with PBS and incubated with ConA-FITC conjugate (ICN, USA) at the concentration of $40 \mu \mathrm{g} / \mathrm{ml}$ for 15 min either at $4^{\circ} \mathrm{C}$ or $37^{\circ} \mathrm{C}$ After three washings with PBS, monolayers were observed under UV-light microscope (Fig.2). In parallel ConA-FITC at $36 \mu \mathrm{g} / \mathrm{ml}$ was treated with $50 \mathrm{mM}$ of D-mannose (Sigma, USA) for $15 \mathrm{~min}$ at $37^{\circ} \mathrm{C}$ before treatment of the cells.

Transmission electron microscopy (TEM): Viral samples collected during the experiments were monitored by conventional negative staining (Fig. 3) (Ueda et al., 1998).

Polyacrylamide gel electrophoresis (PAGE): Cell monolayers supernatant fluids collected during the experiments were also submitted to PAGE (Fig.4) (Herring et al., 1982).

ConA toxicity on MA-104 cells: Cell monolayers established in 96-well tissue culture plates were washed with PBS and maintained with ConA at the concentration of $0.5 \mu \mathrm{g} / \mathrm{ml}, 1.0 \mu \mathrm{g} / \mathrm{ml}, 2.0 \mu \mathrm{g} / \mathrm{ml}$, $2.5 \mu \mathrm{g} / \mathrm{ml}, \quad 3.0 \mu \mathrm{g} / \mathrm{ml}, \quad 3.5 \mu \mathrm{g} / \mathrm{ml}, \quad 4.0 \mu \mathrm{g} / \mathrm{ml}$, $4.5 \mu \mathrm{g} / \mathrm{ml}, 5.0 \mu \mathrm{g} / \mathrm{ml}$ and $10 \mu \mathrm{g} / \mathrm{ml}$ in DMEM for 5 days at $37^{\circ} \mathrm{C}$. The experiment was carried out in triplicate and each concentration was tested in 12 wells per plate. Twelve wells per plate were also maintained for control as mock-treated cells. In another series, monolayers were maintained with $2.5 \mu \mathrm{g} / \mathrm{ml}, 5.0 \mu \mathrm{g} / \mathrm{ml}$ and $10 \mu \mathrm{g} / \mathrm{ml}$ of ConA for 40 min at $37^{\circ} \mathrm{C}$, thoroughly washed with PBS and refed with DMEM, also in triplicate. Mock-treated monolayers were also maintained for control, in triplicate. Monolayers were daily monitored for toxic effect for 5 days.

Virus treatment with ConA: Prior to inoculation, virus suspension was treated with $0.5 \mu \mathrm{g} / \mathrm{ml}$ and $2.5 \mu \mathrm{g} / \mathrm{ml}$ of ConA for $1 \mathrm{~h}$ at $37^{\circ} \mathrm{C}$ The inoculum excess was removed, monolayers washed with PBS and maintained with fresh DMEM, and daily 


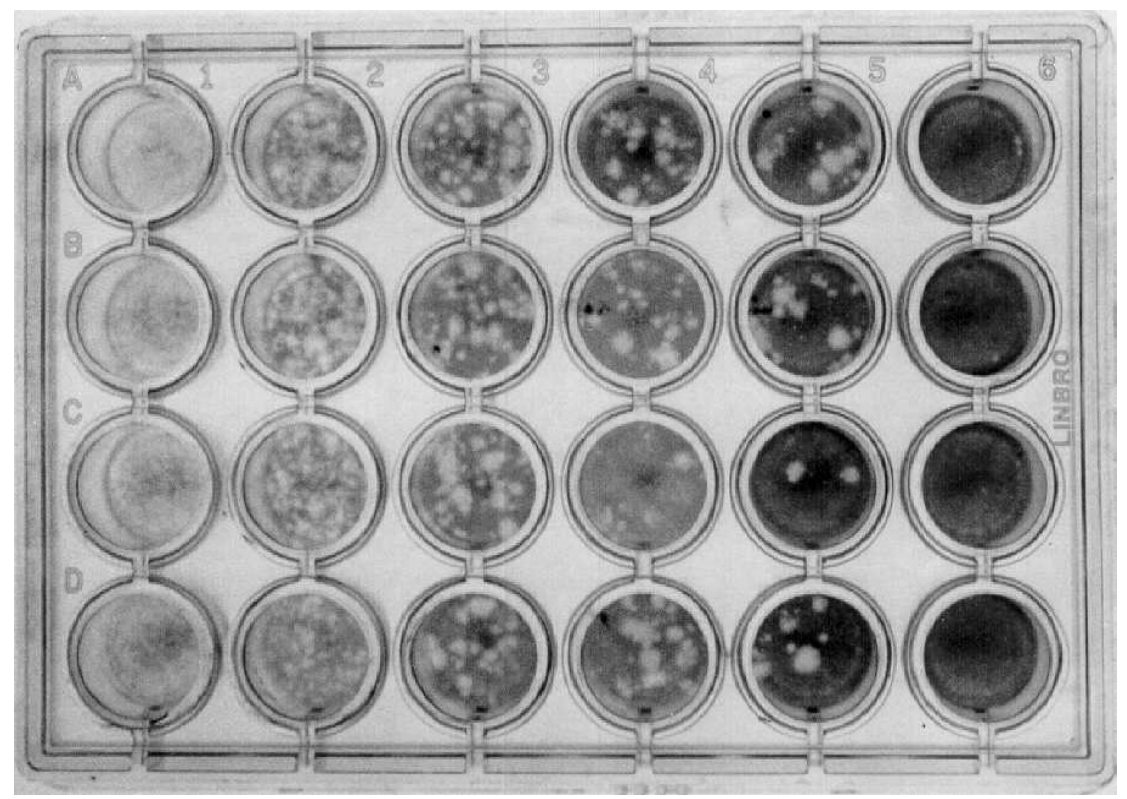

Figure 1 - Plaque assay of rotavirus inoculum diluted to the tenth $\left(10^{-2}\right.$ to $10^{-6}$, lanes 1-5) in MA-104 cell cultures stained with $0.5 \%$ crystal violet five days pi, in quadruplicate. Lane 6, noninfected cell control.

observed for 5 days. Nontreated virus-infected monolayers as well as noninfected cultures were maintained for control. Treated virus suspension was monitored by TEM.

Treatment of cell culture with ConA before the infection: Test tubes established monolayers were treated with $0.5 \mu \mathrm{g} / \mathrm{ml}, \quad 1.25 \mu \mathrm{g} / \mathrm{ml}, \quad 2.5 \mu \mathrm{g} / \mathrm{ml}$, $5.0 \mu \mathrm{g} / \mathrm{ml}$ and $10 \mu \mathrm{g} / \mathrm{ml}$ of ConA for $30 \mathrm{~min}$ at $37^{\circ} \mathrm{C}$, in triplicate. The lectin excess was removed and monolayers were inoculated with the virus. Following attachment, virus inocula were also removed and cultures refed with fresh DMEM. Monolayers treated and noninfected, monolayers nontreated and infected and monolayers nontreated and noninfected were maintained for control. At time intervals of zero, 8, 24, 48, 72 and $96 \mathrm{~h}$ postinfection (pi) monolayers were centrifuged at $2,000 \mathrm{xg}$ for $10 \mathrm{~min}$. The supernatant was collected and $1.0 \mathrm{ml}$ of fresh DMEM was added to the monolayers and submitted to three cycles of freezing/thawing. The supernatant fluids of each time interval and the respective monolayer homogenates were pooled separately, and virus titer determined. In parallel CPE was daily monitored and virus yields evaluated by PAGE.

Treatment of cell culture with ConA after the infection: The experiments were similar to that previously described except that ConA was added at $0.5 \mu \mathrm{g} / \mathrm{ml}$ and $2.5 \mu \mathrm{g} / \mathrm{ml}$ after virus attachment and maintained throughout, and also carried out in triplicate. Cell monolayers treated and noninfected and monolayer nontreated and infected were maintained for control. At time intervals of zero, 8, 24, 48, 72 and $96 \mathrm{~h}$ pi cultures were submitted to three cycles of freezing/thawing. The virus titers were determined in the pooled monolayer homogenates harvested at indicated intervals.

\section{RESULTS}

ConA maintained in MA-104 cell cultures for 5 days, at the concentrations of $0.5 \mu \mathrm{g} / \mathrm{ml}$ to $2.5 \mu \mathrm{g} / \mathrm{ml}$, did not demonstrate any change in the cells that could be considered toxic effect. However, from $3.0 \mu \mathrm{g} / \mathrm{ml}$ to $10 \mu \mathrm{g} / \mathrm{ml}$ cell clumping was observed with increasing intensity at higher concentrations of the lectin. Similarly, no effect was observed during 5 days, when cells were treated for $40 \mathrm{~min}$ only at $2.5 \mu \mathrm{g} / \mathrm{ml}, 5.0 \mu \mathrm{g} / \mathrm{ml}$ and $10 \mu \mathrm{g} / \mathrm{ml}$ of ConA, following the removal of the lectin. When virus suspension was pretreated with ConA at $2.5 \mu \mathrm{g} / \mathrm{ml}$ no change was observed either in the intensity or progression of CPE in comparison to infected and nontreated cultures. Cell monolayers treated with ConA at the 
concentrations $0.5 \mu \mathrm{g} / \mathrm{ml}$ to $10 \mu \mathrm{g} / \mathrm{ml}$ before virus inoculation did not affect much the kinetics of virus growth in comparison to nontreated cells. It was observed that at $0.5 \mu \mathrm{g} / \mathrm{ml}$ to $2.5 \mu \mathrm{g} / \mathrm{ml}$ of the lectin no difference was found in the total virus titer. Similarly, cell-associated virus titer and that of the supernatant fluid did not demonstrate any difference in comparison to nontreated cells (Figs. 5 to 7). At the concentration of $5.0 \mu \mathrm{g} / \mathrm{ml}$ and $10 \mu \mathrm{g} / \mathrm{ml}$ however, a decrease of 1 to $2 \log$ was
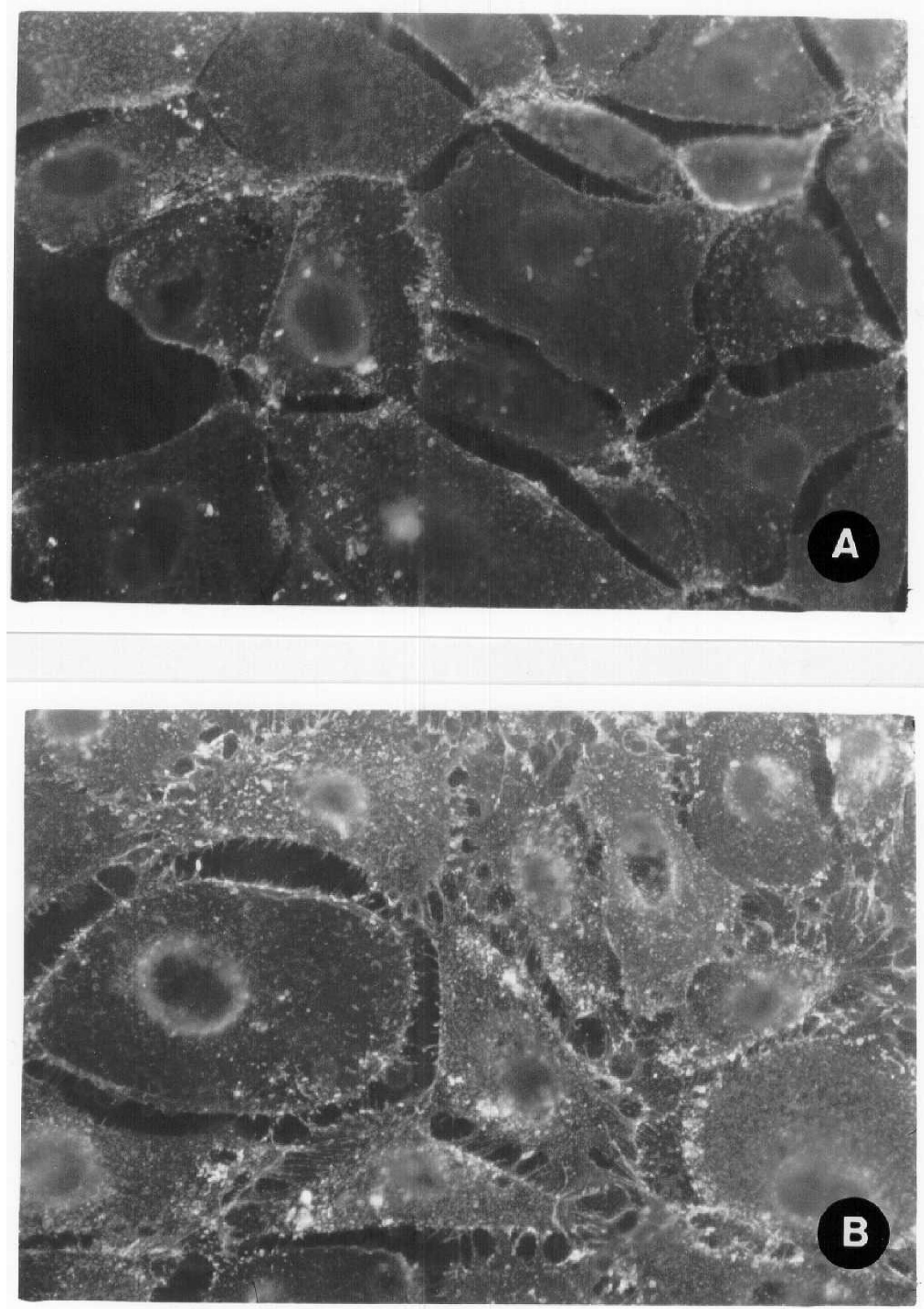

Figure 2 - Fluorescence assay of MA-104 cell cultures incubated with ConA-FITC for $15 \mathrm{~min}$ at $4^{\circ} \mathrm{C}$ (A) showing labeling mainly at the cell surface and at $37^{\circ} \mathrm{C}$ also in the cytoplasm (B). 200X.

detected in cell-associated virus titer at time interval of 24 to $72 \mathrm{~h}$ pi in comparison to that of nontreated cells. Virus titer in the supernatant fluid at the same period of time showed no difference between treated and nontreated cultures (Figs. 8 and 10). When ConA was added to virus-infected cultures at the concentration of $0.5 \mu \mathrm{g} / \mathrm{ml}$ and $2.5 \mu \mathrm{g} / \mathrm{ml}$ soon after attachment and maintained 
throughout, the kinetics of virus growth was not altered (Figs. 9 and 11). Although no difference was detected in virus titer, at the concentration of $2.5 \mu \mathrm{g} / \mathrm{ml}$, the development of CPE was delayed in relation to nontreated cultures. Twenty-four $\mathrm{h}$ pi approximately $5 \%$ of treated cells presented CPE, similarly to that of nontreated control cells. Fortyeight $\mathrm{h}$ pi both treated and nontreated infected cultures showed that $10-20 \%$ of the cells were affected. From 72 h to 96 h pi monolayers kept with ConA maintained CPE similarly to that

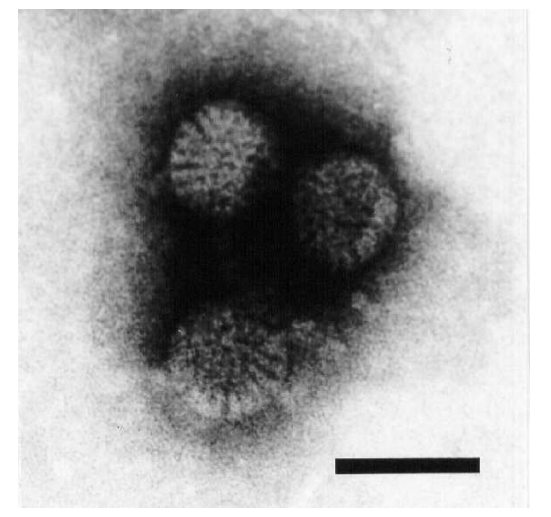

Figure 3 - Negative staining electron micrography of rotavirus inoculum submitted to the treatment with $2.5 \mu \mathrm{g} / \mathrm{ml}$ of ConA. Bar: $100 \mathrm{~nm}$. observed at $48 \mathrm{~h}$ pi in that $10-20 \%$ of the cells presented CPE. However, cultures in the absence of lectin showed CPE in $60 \%$ at the same time interval. At time interval from $96 \mathrm{~h}$ to $144 \mathrm{~h}$ pi 70 $90 \%$ of the nontreated cells showed CPE but only $20 \%$ in treated cultures.

\section{DISCUSSION}

The interaction of lectins on virus replication has been studied in particular with the enveloped viruses due to the involvement of surface structures of both viral and cell origin integrated in biological membranes. The affinity among these structures represents the recognition for specific cell receptors for virus binding and triggering the infectious process. Any mechanism that interferes with the recognition may signify an important role in virus infectivity as well as for the understanding of virus penetration into susceptible host cell. Presumably the affinity and reactivity among cellular and virus receptors are intensively mediated by glycoprotein and glycolipids with major role of the carbohydrate residues. Therefore, the highly specific interaction of lectins with sugars would point out for the possibility of positive or negative modulation of virus binding to host cells. As previously described, lectins have been used as valuable tool for monitoring virus

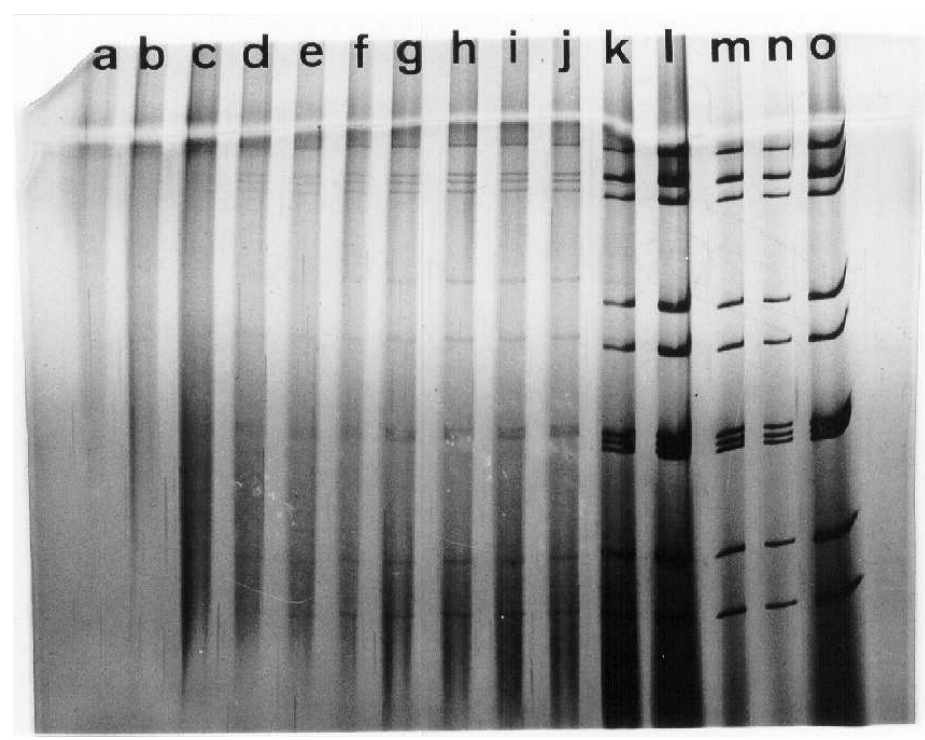

Figure 4 - Polyacrylamide gel electrophoresis of rotavirus double-stranded RNA segments from the supernatant fluids of cell cultures treated before the infection with ConA at the concentration of $2.5 \mu \mathrm{g} / \mathrm{ml}$, collected at $8,24,48,72$ and $96 \mathrm{~h}$ pi. Lanes b, $\mathrm{d}, \mathrm{f}, \mathrm{h}$, and $\mathrm{j}$ with ConA treatment. Lanes a, c, e, g and i without ConA treatment. Lanes k-o human RV run as control. 
binding/replication, in particular with enveloped viruses. ConA among the lectins has been demonstrated as inhibitor of various enveloped viruses, such as Sendai virus, herpes simplex virus, Newcastle Disease virus, Epstein Barr virus, Vesicular Stomatitis virus, tick-borne encephalitis virus, fowl plague virus and rabies virus (Becht et al, 1972; Okada \& Kim, 1972; Ito \& Barron, 1974; Poste et al., 1974; Cartwright, 1977; Takehara, 1979; Khélifa \& Menezes, 1982; Conti \& Tsiang, 1985; Okamoto et al., 1997). On the other hand, a few data are available concerning the effect of ConA on the replication of nonenveloped viruses (Okada \& Kim, 1972; Ito \& Barron, 1974; Lonberg-Holm, 1975). Svensson (1984) demonstrated that triple-layered human RV particles were aggregated by ConA and this effect was either dissociated or inhibited with $\alpha$-metil-Dmannoside. Receptors for ConA are found in several animal cells such as mouse peritoneal macrophages, Hela cells, chicken embryo-related cells (CER), human amnion (FL cells), MDBK cells, BHK and mouse fibroblast (3T3) (ArndtJovin \& Berg, 1971; Conti \& Tsiang, 1985; Kopecky et al., 1991; Okamoto et al., 1997). Presently, we demonstrated the binding of labeled ConA to MA-104 cells at the concentration of $40 \mu \mathrm{g} / \mathrm{ml}$. At the incubation temperature of $4^{\circ} \mathrm{C}$ labeling was more intense at the cell surface and at $37^{\circ} \mathrm{C}$ it was also observed in the cytoplasm suggesting active internalization of part of the lectin previously bound to cell surface. Sialylated compounds at the cell surface have been pointed out as critical for the binding of several viruses including RV. In fact, the presence of these compounds was shown to be essential for binding and hemagglutin activity for RV (SA-11 and bovine strain), however, it was not true for $\mathrm{Wa}$, KUN and MO strains of human RV (Fukudome et al., 1989). Similarly, Méndez et al. (1993) demonstrated that sialic acid was not necessary for the infectivity of certain mutant strains of RV in MA-104 cells. Binding of RV in a mixture of nonsialylated glycolipids from bovine brain and mouse intestine was demonstrated suggesting thatattachment and penetration of the virus dependupon different cellular components, and that the former takes place in two stages, dependent and independent of sialylated compounds at cell surface (Willoughby et al., 1990; Srnka et al., 1992; Méndez et al., 1993; Ludert et al., 1996; Isa et al., 1997; Rolsma et al.,
1998). The demonstration that VP4 and VP7, respectively present sites for recognition of $\alpha 2 \beta 1$ and $\alpha 4 \beta 1$, thought to be RV receptors, suggested alternative way for virus penetration; however sugar residues were not considered (Coulson et al., 1997; Hewish et al., 2000). Wheat agglutinin and ConA were previously shown to inhibit several viruses for binding to true receptors or to inhibit progeny maturation and liberation (Ziegler \& Pozos, 1981; Okada \& Kim, 1972; Poste et al., 1974; Lonberg-Holm 1975; Cartwright, 1977; Khélifa \& Menezes, 1982; Conti \& Tsiang, 1985). When we treated the cells with ConA before virus infection, we thought of the possibility of the lectin to bind to cell receptors and enhance binding and penetration of RV by the interaction with VP7. On the other hand, ConA could also mask cell receptors for VP7 inhibiting virus binding. The kinetics of cell-associated and supernatant fluid virus growth of cell monolayers previously treated with ConA did not demonstrate differences at $0.5 \mu \mathrm{g} / \mathrm{ml}$ and $2.5 \mu \mathrm{g} / \mathrm{ml}$ in comparison to nontreated cells. At the concentrations of $5.0 \mu \mathrm{g} / \mathrm{ml}$ to $10 \mu \mathrm{g} / \mathrm{ml}$, however a decrease of 1 and $2 \log$ in cell-associated virus titer was demonstrated at the interval of $24-72 \mathrm{~h}$ pi. No difference was detected in the development of CPE in ConA-treated cells in comparison to nontreated cultures. These results suggest that ConA did not interfere with binding and/or penetration of the virus. It may be due to the low concentration of ConA used in comparison to experiments previously described where concentration of lectin used varied from $12.5 \mu \mathrm{g} / \mathrm{ml}$ to $1000 \mu \mathrm{g} / \mathrm{ml}$. At physiological $\mathrm{pH}$ ConA is found as tetramer and capable to form crossed links at cell surface (Gunther et al., 1973; Reeke et al, 1975). We, therefore, justify the use of low concentration of the lectin in order not to block physically cell receptors by the excess of ConA but rather allow the interaction in a stechiometric ratio. In these conditions, however, it could be possible that ConA did not allow additional sites for virus binding more than those already present at the cell surface. Nevertheless, the decrease in cell-associated virus titer may suggest a temporal interference with virus morphogenesis, eventually with glycosylation sites of viral protein critical for virus assembly. In a second series of our experiment, ConA was added after virus infection and maintained throughout. 
A

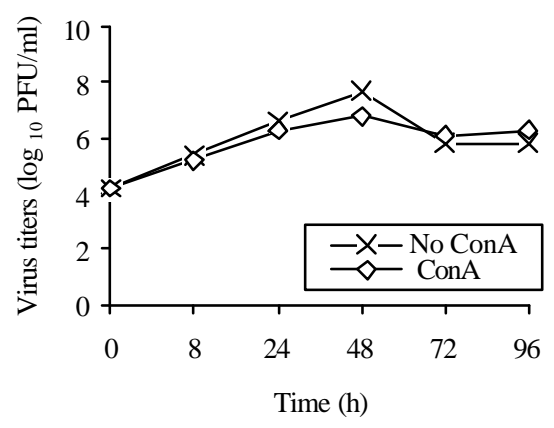

B

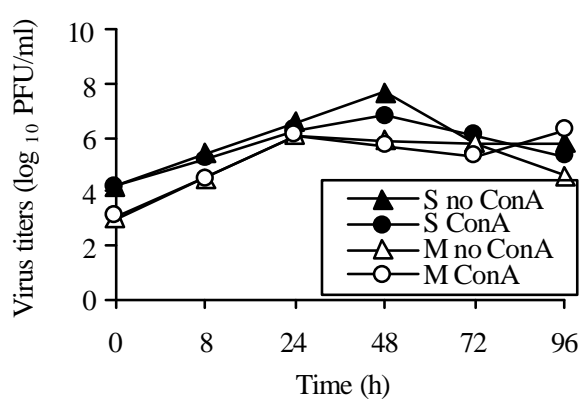

Figure 5 - The kinetics of viral growth in cell culture treated with $0.5 \mu \mathrm{g} / \mathrm{ml}$ of ConA prior to infection. ATotal virus titer. B-Supernatant fluid $(\mathrm{S})$ and cell monolayer (M) virus titers.

Due to the toxicity of the lectin, we used the concentration of $0.5 \mu \mathrm{g} / \mathrm{ml}$ and $2.5 \mu \mathrm{g} / \mathrm{ml}$. However we could not detect any alteration in viral infectivity. RV (SA11) and bovine strain present, respectively one and two or three sites of glycosylation at VP7. It was shown that bovine colectins with specificity to mannose neutralize the infectivity of RV (SA11) at higher concentration than those necessary for neutralization of bovine strain, and that neutralization was due to the aggregation of virus particles (Reading et al., 1998). In our experiment we expected that ConA could interfere with second generation of progeny, however, possibly due to low concentrations of ConA, this effect was not demonstrated. The observation of the inhibitory effect of ConA on the replication of several viruses, as previously cited, used much higher concentration of the lectin (Becht et al, 1972; Poste et al., 1974; Lonberg-Holm 1975; Cartwright, 1977; Khélifa \& Menezes, 1982; Conti \& Tsiang, 1985; Grail \& Norval, 1986).
A

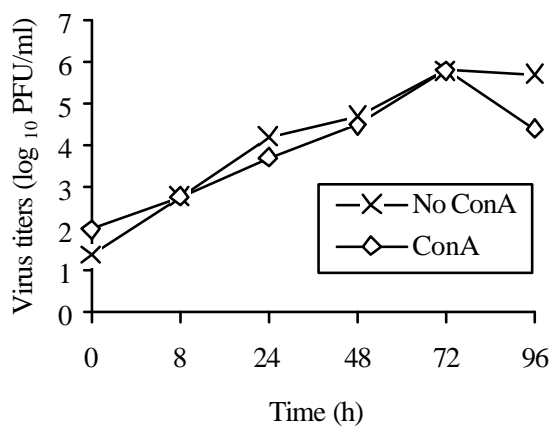

B

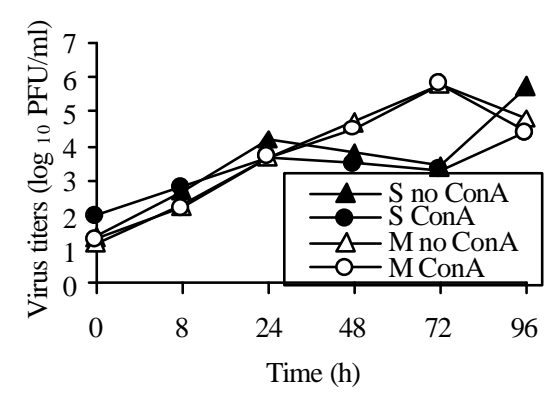

Figure 6 - The kinetics of viral growth in cell culture treated with $1.25 \mu \mathrm{g} / \mathrm{ml}$ of ConA prior to infection. ATotal virus titer. B-Supernatant fluid (S) and cell monolayer $(\mathrm{M})$ virus titers.

Ito \& Barron (1974) pretreated nonenveloped virus with ConA at $100 \mu \mathrm{g} / \mathrm{ml}$ and observed that it did not alter echovirus and adenovirus replication. Ruggeri \& Greenberg (1991) demonstrated that neutralization of RV infectivity occurred only when most of virus receptors was blocked. It is possible that in our experiment RV was not inhibited because higher concentration of the lectin would be required. Although we were unable to demonstrate the interference of ConA in the replication of $\mathrm{RV}$, it was observed that the presence of the lectin throughout the experiment caused a delay in the development of CPE. We suggested that internalized ConA may have interfered with virus proteins responsible for the toxic effect in the host cells. It was demonstrated that NSP4, a nonstructural viral protein with two sites of glycosylation rich in mannose, increases intracellular calcium concentration and this has been associated with CPE development (Tian et al., 1994; Ball et al., 1996; Estes et al., 1996; Ruiz et al., 1996; Tian et al., 1996; Dong et al., 
1997; Newton, 1997). In conclusion, our results demonstrated that ConA neither inhibited consistently RV (SA11) replication nor enhanced the infectivity. However, we showed that it inhibited virus citotoxicity suggesting interference on the stage of newly synthesized virus proteins.

\section{A}

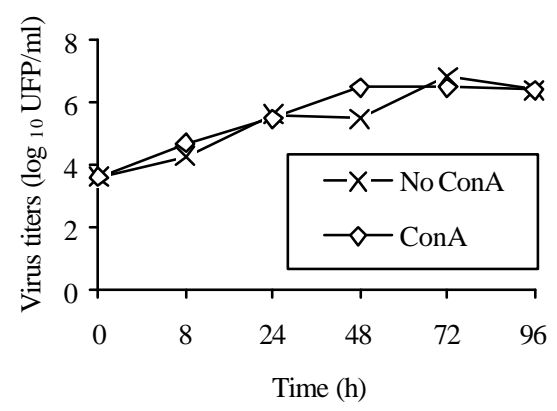

B

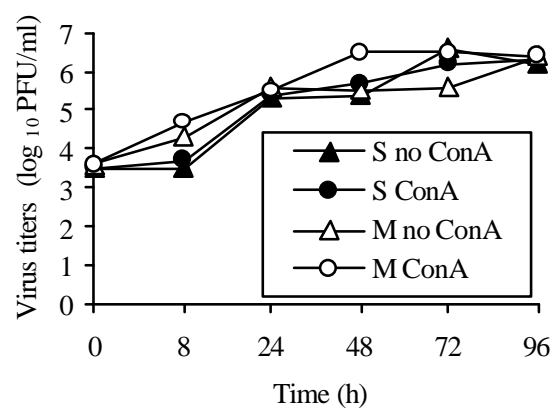

Figure 7 - The kinetics of viral growth in cell culture treated with $2.5 \mu \mathrm{g} / \mathrm{ml}$ of ConA prior to infection. ATotal virus titer. B-Supernatant fluid (S) and cell monolayer $(\mathrm{M})$ virus titers.

\section{ACKNOWLEDGEMENTS}

The authors wish to thank to CAPES and CPG/ UEL for financial support. This work is part of M.Sc. manuscript of BSH who was in receipt of scholarship also granted by CAPES.

\section{RESUMO}

A infecciosidade do rotavírus cepa SA-11 foi estudada em cultura de células MA-104 em presença de concanavalina A (ConA). Foi demonstrada a presença de receptores para a ConA nestas células através de ensaio de fluorescência e bloqueio específico dos mesmos através de
D-manose. A cinética de replicação viral foi realizada pelo método de plaque e o vírus monitorado, pontualmente, pela microscopia eletrônica de transmissão e eletroforese em gel de poliacrilamida. Concluímos que a ConA não afetou consistentemente a replicação viral, entretanto interferiu no efeito citopático.

$\mathbf{A}$

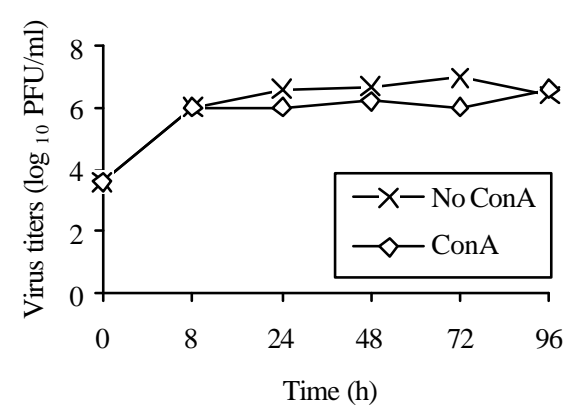

B

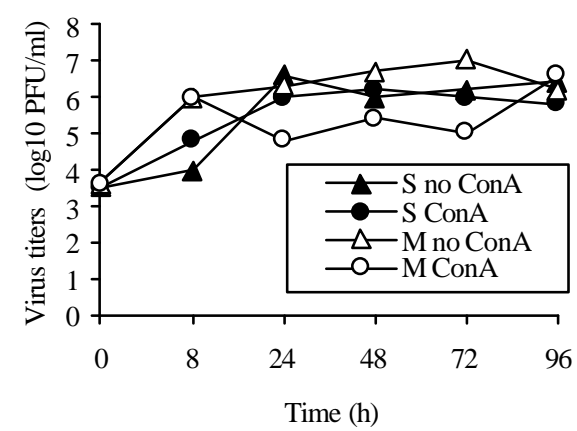

Figure 8 - The kinetics of viral growth in cell culture treated with $5.0 \mu \mathrm{g} / \mathrm{ml}$ of ConA prior to infection. ATotal virus titer. B-Supernatant fluid (S) and cell monolayer (M) virus titers.

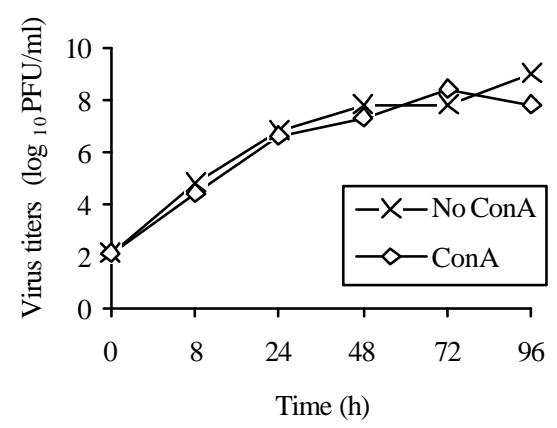

Figure 9 - The kinetics of viral growth in cell cultures treated and maintained with $0.5 \mu \mathrm{g} / \mathrm{ml}$ of ConA. 
A

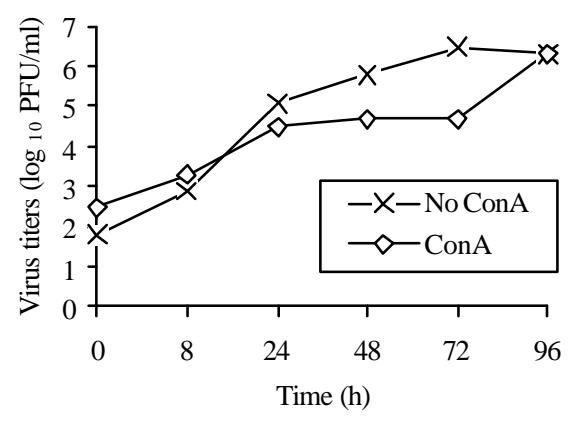

B

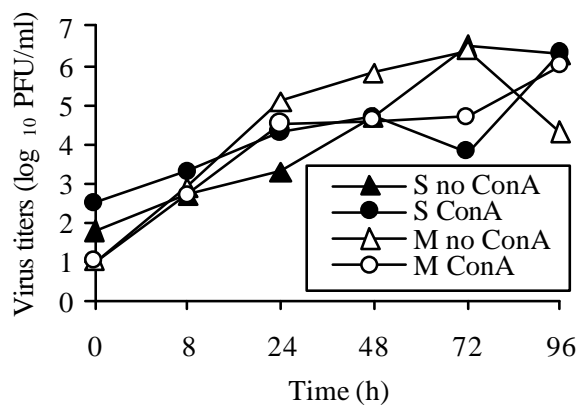

Figure 10 - The kinetics of viral growth in cell culture treated with $10 \mu \mathrm{g} / \mathrm{ml}$ of ConA prior to infection. A- Total virus titer. B-Supernatant fluid (S) and cell monolayer (M) virus titers.

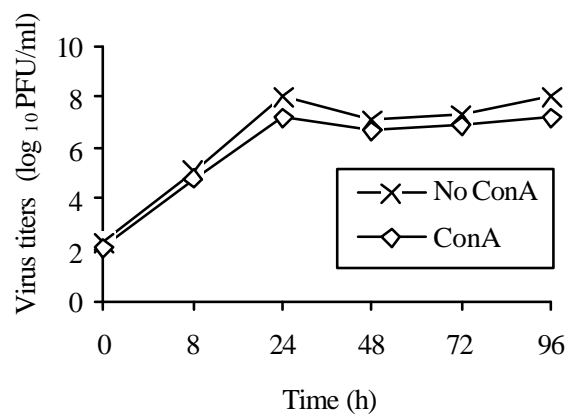

Figure 11 - The kinetics of viral growth in cell cultures treated and maintained with $2.5 \mu \mathrm{g} / \mathrm{ml}$ of ConA.

\section{REFERENCES}

Arndt-Jovin, D. J. and Berg, P. (1971), Quantitative binding of ${ }^{125}$ I-concanavalin $A$ to normal and transformed cells. J. Virol., 8, 716-721.

Ball, J. M.; Tian, P.; Zeng, C. Q.; Morris, A. P. and Estes, M. K. (1996), Age-dependent diarrhea induced by a rotaviral nonstructural glycoprotein. Science, 272, 101-104.

Becht, H. ; Rott, R. and Klenk, H. D. (1972), Effect of concanavalin A on cells infected with enveloped RNA viruses. J. Gen. Virol., 14, 1-8.

Both, G. W.; Bellamy, A. R. and Mitchel, D. B. (1994), Rotavirus protein structure and function. Cur. Top. Microbiol. Immunol., 185, 67-104.

Bridger, J. C.; Tauscher, G. I. and Desselberger, U. (1998), Viral determinants of rotavirus pathogenicity in pigs: evidence that the fourth gene of a porcine rotavirus confers diarrhea in the homologous host. $J$. Virol., 72, 6929-6931.

Burke, B. and Desselberger, U. (1996), Rotavirus pathogenicity. Virology, 218, 299-305.
Calafat, J. and Hageman, P. C. (1972), Binding of concanavalin A to the envelope of two murine RNA tumor viruses. J. Gen Virol., 14, 103-106.

Cartwright, B. (1977), Effect of concanavalin A on vesicular stomatitis virus maturation. J. Gen. Virol., 34, 249-256.

Conti, C. and Tsiang, H. (1985), Effect of concanavalin A on the early events of rabies virus infection of CER cells. Intervirology, 24, 166-169.

Coulson, B. S.; Londrigan, S. L. and Lee, D. J. (1997), Rotavirus contains integrin ligand sequences and a disintegrin-like domains that are implicated in virus entry into cells. Proc. Natl. Acad. Sci. USA, 94, 53895394.

Dong, Y.; Zeng, C. Q. Y.; Ball, J. M.; Estes, M. K. and Morris, A. P. (1997), The rotavirus enterotoxin NSP4 mobilizes intracellular calcium in human intestinal cells by stimulating phospholipase C-mediated inositol 1,4,5-triphosphate production. Proc. Natl. Acad. Sci. USA, 94, 3960-3965.

Estes, M. K. (1996), Rotaviruses and their replication. In- Virology, eds. B. N. Fields; D. M. Knipe; P. M. Howley et al., Lippincott-Raven, Philadelphia, pp.1625-1655.

Fukudome, K.; Osamu, Y. and Konno, T. (1989), Comparison of human, simian and bovine rotavirus for requirement of sialic acid in hemagglutination and cell adsorption. Virology, 172, 192-205.

Grail, A. and Norval, M. (1986), Effect of concanavalin A and succinyl concanavalin A on Cytomegalovirus replication in fibroblasts. Arch. Virol., 91, 61-71.

Gunther, G. R.; Wang, J. L.; Yahara, I.; Cunningham, B. A. and Edelman, G.M. (1973), Concanavalin A derivatives with altered biological activities. Proc. Natl. Acad. Sci USA, 70, 1012-1016.

Haywood, A. M. (1994), Virus receptors: binding, adhesion strengthening, and changes in viral structure. J. Virol., 68, 1-5. 
Herring, A. J.; Inglis, N. F.; Ojeh, C. K.; Snodgrass, D. R. and Menzies, J. D. (1982), Rapid diagnosis of rotavirus infection by direct detection of viral nucleic acid in silver stained polyacrylamide gels. J. Clin. Microbiol., 16, 473-477.

Hewish, M. J.; Takada, Y. and Coulson, B. S. (2000), Integrins alpha2beta1 and alpha4beta1 can mediate SA11 rotavirus attachment and entry into cells. $J$. Virol., 74, 228-236.

Isa, P.; López, S.; Segovia, L. and Arias, C. F. (1997), Functional and structural analysis of the sialic acidbinding domain of rotaviruses. J. Virol., 71, 67496756.

Ito, M. and Barron, A. L. (1974), Inactivation of herpes simplex virus by concanavalin A. J. Virol., 13, 13121318.

Kapikian, A. Z. and Chanock, R. M. (1996), Rotaviruses. In-Virology eds. B.N. Fields; D.M. Knipe; P.M. Howley at al., Lippincott-Raven, Philadelphia, pp.1657-1708.

Khélifa, R. and Menezes, J. (1982), Epstein-Barr virus lynmphoid cell interactions. III. Effect of concanavalin A and saccharides on Epstein-Barr virus penetration. J. Virol., 42, 402-410.

Kirkwood, C. D.; Bishop, R. F. and Coulson, B. S. (1998), Attachment and growth of human rotaviruses RV-3 and S12/85 in Caco-2 cells depend on VP4. J. Virol., 72, 9348-9352.

Kopecky, J.; Grubhoffer, L. and Tomková, E. (1991), Interaction of tick/borne encephalitis virus with mouse peritoneal macrophages. The effect of antiviral antibody and lectin. Acta Virol., 35, 218-225.

Lonberg-Holm, K. (1975), The effects of concanavalin A on the early events of infection by rhinovirus type 2 and poliovirus type 2. J. Gen. Virol., 28, 313-327.

Ludert, J. E.; Feng, N.; Yu, J. H.; Broome, R. L.; Hoshino, Y. and Greenberg, H. B. (1996), Genetic mapping indicates that VP4 is the rotavirus cell attachment protein in vitro and in vivo. J. Virol., 70, 487-493.

Méndez, E.; Arias, C. F. and López, S. (1993), Binding to sialic acids is not an essential steps for the entry of animal rotavirus to epithelial cells culture. J. Virol., 67, 5253-5259.

Méndez, E.; Arias, C. F. and López, S. (1996), Interactions between the two surface proteins of rotavirus may alter the receptor-binding specificity of the virus. J. Virol., 70, 218-1222.

Miki, T. (1980), Concanavalin A agglutinability of some enveloped RNA viruses modified by host cell transformation. Microbiol. Immunol., 24, 429-438.

Murray, R. K. (1994), Glicoproteinas ; proteoglicanos. In-Harper: Bioquímica, eds. K. M. Murray; D. K. Granner; P.A. Mayes and V. W. Rodwell, Rio de Janeiro : Atheneu, pp.631.
Newton, K.; Meyer, J. C.; Bellamy, A. R. and Taylor, J. A. (1997), Rotavirus nonstructural glycoprotein NSP4 alters plasma membrane permeability in mammalian cells. J. Virol., 71, 9458-9465.

Okada, Y. and Kim, J. (1972), Interaction of concanavalin A with enveloped viruses and host cells. Virology, 50, 507-515.

Okamoto, K.; Oki, T.; Igarashi, Y.; Tsurudome, M.; Nishio, M.; Kawano, M.; Komada, H.; Ito, M.; Sakakura, Y. and Ito, Y. (1997), Enhancement of human parainfluenza virus-induced cell fusion by pradimicin, a low molecular weight mannose-binding antibiotic. Med. Microbiol. Immunol., 186, 101-108.

Poste, G.; Alexander, D. J.; Reeve, P. and Hewlett, G. (1974), Modification of Newcastle disease virus release and cytopathogenicity in cells treated with plant lectins. J. Gen. Virol., 23, 255-270.

Prasad, B. V. V. and Estes, M. K. (1997), Molecular basis of rotavirus replication. In- Chiu, W.; Burnett, R. M. and Garcea, R. L. Structural Biology of Viruses. New York: Oxford University Press, pp. 239-268.

Reading, P. C.; Holmskov, U. and Anders, E. M. (1998), Antiviral activity of bovine collectins against rotaviruses. J. Gen. Virol., 79, 2255-2263.

Reeke Jr., G. N.; Becker, J. W.; Cunningham, B. A.; Wang, J. L.; Yahara, I. and Edelman, G. M. (1975), Structure and function of concanavalin A. Adv. Exp. Med. Biol., 55,13-33.

Rolsma, M. D.; Kuhlenschmidt, T. B.; Gelberg, H. B. and Kuhlenschmidt, M. K. (1998), Structure and function of a ganglioside receptor for porcine rotavirus. J Virol., 72, 9079-9091.

Ruggeri, F. M. and Greenberg, H. B. (1991), Antibodies to the trypsin cleavage peptide VP8* neutralize rotavirus by inhibiting binding of virions to target cells in culture. J. Virol., 65, 2211-2219.

Ruiz, M. C.; Charpilienne, A.; Liprandi, F.; Gajardo, R.; Michelangeli, F. and Cohen, J. (1996), The concentration of $\mathrm{Ca}^{2+}$ that solubilizes outer capsid proteins from rotavirus particles is dependent on strain. J. Virol., 70, 4877-4883.

Srnka, C. A.; Tiemeyer, M.; Gilbert, J. H.; Moreland, M.; Schweinbruger, H.; De Lappe, B. W.; James, P. G.; Gant, T.; Willoughby, R. E.; Yolken, R. H.; Nashed, M. A.; Abbas, S. A. and Laine, R. A. (1992), Cell surface ligands for rotavirus: mouse intestinal glycolipids and syntetic carbohydrate analogs. Virology, 190, 794-805.

Svensson, L. (1984), Identification of an outer capsid glycoprotein of human rotavirus by Concanavalin A. J. Gen. Virol., 65, 2183-2190.

Takehara, M. (1979), Effect of concanavalin A on viral infectivity, maturation and cytopathogenicity in vesicular stomatitis virus-infected cells. Kobe J. Med. Sci., 25, 205-216. 
Tian, P.; Hu, Y.; Schilling, W. P.; Lindsay, D. A.; Eiden, J. and Estes, M. K. (1994), The nonstructural glycoprotein of rotavirus affects intracellular calcium levels. J. Virol., 68, 251-257.

Tian, P. Ball, J. M.; Zeng, C. Q. and Estes, M. K. (1996), Rotavirus protein expression is important for virus assembly and pathogenesis. Arch. Virol. Suppl., 12, 69-77.

Ueda, M.; Tanaka, H.; Kisielius, J. J.; Pires, M. F. C. and Weigl, D. R. (1998), Importance of electron microscopy and its contribution to viral diagnosis. Virus Rev. Res., 3, 9-36.
Willoughby, R. E.; Yolken, R. H. and Schnaar, R. L. (1990), Rotaviruses specifically bind to the neutral glycosphingolipid asialo-GM1. J. Virol., 64, 4830-4835. Ziegler, R. J. and Pozos, R. S. (1981), Effects of lectins on peripheral infection by Herpes Simplex Virus of rat sensory neurons in culture. Infect. Immun., 34, 588-595.

Received: May 05, 2000; Revised: July 18, 2000; Accepted: December 08, 2000. 


\section{PÁGINA}

\section{EM}

BRANCO 